\title{
PERFORMANCE CHARACTERISTICS OF ADSORPTIVE REGENERATOR OF LOW-POTENTIAL HEAT AND MOISTURE BASED ON COMPOSITE ADSORBENTS 'SILICA GEL - SODIUM SULPHATE’ SYNTHESIZED BY SOL - GEL METHOD
}

\author{
Belyanovskaya E.A. ${ }^{1}$, PhD, docent, Lytovchenko R.D. ${ }^{1}$, postgraduate student, \\ Sukhyy K.M. ${ }^{1}$ SciD, Prof., Sukhyy M.P. ${ }^{1}$ PhD, Prof., Gubinskyi M.V. ${ }^{2}$, SciD, Prof. \\ ${ }^{1}$ State Higher Education Institution «Ukrainian State University of Chemical Engineering», \\ Dnipro, Ukraine; ${ }^{2}$ National Metallurgical Academy of Ukraine, Dnipro, Ukraine
}

\begin{abstract}
The performance characteristics of the adsorptive regenerator of the low-potential heat and moisture on basis of the composite sorbents 'silica gel - sodium sulfate' synthesized by sol-gel method are stud$i e d$. The mathematical model and algorithm for determining the basic parameters of adsorptive regenerator exploitive processes in the housing and communal services sector are developed. The proposed algorithm includes calculating the volume of air passed through the layer of heat-accumulating material, the concentration of water in the flow at the exit from the regenerator, the adsorption, the heat of adsorption, the final temperature of the cold air, the air temperature after mixing the cold air from the street and the warm air in the room at the warm end of the regenerator during inflow, calculation of the final concentration of water in the flow at the cold end of the regenerator, the volume of air passing through the layer of heat-accumulating material, adsorption and heat of adsorption, the final temperature of the air at the cold end of the regenerator, the air temperature after mixing of the cold air from the street and the warm air from the room at the cold end of regenerator during outflow, determining the temperature efficiency coefficient, summarized adsorption and maximal adsorption time. The correlation of air temperatures near the warm and cold end of the regenerator, as well as the thermal efficiency coefficients stated by the results of calculations according to the proposed algorithm and experimental way is confirmed. The mathematical modeling of the processes of operation of adsorption regenerators on the basis of 'silica gel - sodium sulfate' composites in the conditions of the typical ventilation system of residential premises is carried out. The dependences of the temperature efficiency coefficient vs. the time of switching air flows and the velocity of air flow, as well as the temperatures of external and internal air under stationary conditions are shown. The results of the research can be used in the development of energy-efficient ventilation systems and devices for residential and warehouse premises.
\end{abstract}

Key words: adsorptive heat and moisture regenerator, temperature efficiency coefficient.

\section{ХАРАКТЕРИСТИКИ ПРОЦЕСІВ ЕКСПЛУАТАЦЇ̈ АДСОРБЦЙНОГО РЕГЕНЕРАТОРА НИЗЬКО-ПОТЕНЦЙНОГО ТЕПЛА ТА ВОЛОГИ НА ОСНОВІ КОМПОЗИТНИХ АДСОРБЕНТІВ «СИЛІКАГЕЛЬ - НАТРІЙ СУЛЬФАТ», СИНТЕЗОВАНИХ ЗОЛЬ - ГЕЛЬ МЕТОДОМ}

Бєляновська О.А. ${ }^{1}$, к.т н., доцент, Литовченко Р.Д. ${ }^{1}$, аспірант, Сухий К.М. ${ }^{1}$, д-р техн. наук, професор, Сухий М.П. ${ }^{1}$ к.т.н., професор, Губинський М.В. ${ }^{2}$, д-р техн. наук, професор ${ }^{1}$ ДВНЗ «Украйнський державний хіміко-технологічний університет», м. Дніпро, ${ }^{2}$ Національна металургійна академія Украйни, м. Дніпро

\begin{abstract}
Анотація. Досліджені експлуатаційні характеристики адсорбиійного регенератора низькопотенційного тепла та вологи на основі композитних сорбентів «силікагель - натрій сульфат», синтезованих золь - гель методом. Розроблені математична модель та алгоритм визначення базових параметрів процесів експлуатації адсорбційного регенератора в умовах сектора житлово-комунального господарства. Запропонований алгоритм включає розрахунок об'єму повітря, який пройшов через шар теплоакумулюючого матеріалу, концентрації води в повітрі на виході з теплового акумулятора, адсорбиії, теплоти адсорбції, кінцевої температури холодного повітря, температури повітря після змішування холодного повітря з вулиці та теплого повітря в приміщенні при подачі, розрахунок концентрації води в повітрі на виході з теплового акумулятора, об'єму повітря, який пройшов через шар теплоакумулюючого матеріалу, адсорбиї та теплоти адсорбиїі, кінцевої температури теплого повітря, температури повітря після змішування холодного повітря з вулиці та теплого повітря з приміщення при викиді, визначення температурного коефіцієнта корисної дії, сумарної адсорбиії та часу досягнення максимальної адсорбиії. Підтверджена кореляція температур повітря біля теплого та холодного кінці регенератора, а також теплових коефіцієнтів корисної дї, встановлених за результатами розрахунків
\end{abstract}

Наукові праці, Том 82, випуск 1 Scientific Works, Volume 82, Issue 1 
згідно запропонованого алгоритму та дослідним иляхом. Проведено математичне моделювання проиесів експлуатації адсорбційних регенераторів на основі композитів «силікагель - натрій сульфат» в умовах типової системи вентиляиії житлових приміщень. Показана залежність теплового коефіцієнта корисної дії від часу перемикання потоків повітря, швидкості руху потоків повітря, а також температур зовнішнього та внутрішнього повітря в стаціонарних умовах. Максимальні значення теплових коефічієнтів корисної дї встановлені при швидкості вологого повітря близько 0,22 - 0,32 м/с та часу перемикання потоків 5 - 10 хв.. Виявлено вплив швидкості руху потоків вологого повітря на час досягнення максимальної адсорбціі. Результати проведеного дослідження можуть бути використані при розробці енергоефективних вентиляиійних систем та пристроїв для житлових та складських приміщень.

Ключові слова: адсорбційний регенератор тепла та вологи, тепловий коефіцієнт корисної дії тепла.

One of the most important and serious problems in the operation of centralized heating systems in the housing and utilities sector, as well as energy-efficient autonomous heating systems, is heating and ventilation load, in particular heating of the inflow air, as well as the periodic increase in the concentration of carbon dioxide in the space air [1]. According to the sanitary-hygienic requirements, periodic ventilation of residential premises is necessary, which as a consequence the relatively low temperatures in Ukraine in the winter, leads to significant heat expenses. In modern systems of heat supply for the heating of the inflow air, recuperative heat exchangers (plate heat exchangers with cross flow, plate heat exchangers with counterflow, counter flow channel heat exchangers, partially recirculated system) and regenerative (rotary heat exchanger, static heat exchanger) [2]. The disadvantages of the first should be attributed a significant volume, thermodynamically unfavorable flows, insignificant surface of heat transfer, the use of liquid thermal fluid and expensive additional equipment. Additionally, the operation of such devices is considerably complicated by the formation of ice on the cold end of the device. The disadvantage of others [2] is the low efficiency coefficient of ventilation of apartments, the lack of separate air control; fresh air pollution resulted from constant change of air direction.

Traditional ventilation and air conditioning systems based on steam compression machines also provide air cooling to temperatures lower than dew point and heating to acceptable temperatures. Such devices represent significant energy consumption, which requires fossil fuels input and complicates the utilization of heat energy.

Silica gel [3] and aluminophosphate zeolite [4] are suggested to use for adsorptive dehumidification of air. Promising materials for the regeneration of heat and moisture are composite sorbents of the type 'salt in the porous matrix' [5]. Devices based on them allow to maintain an acceptable temperature and humidity in domestic environment [6,7]. Adsorptive heat storage devices were used in heat supply systems in the Netherlands, Germany and Japan [8]. But the active introduction of such devices along with the low quality of the materials used is retarded by the lack of an algorithm for their calculation, which allows to simulate and investigate the processes of their operation in the conditions of real ventilation systems.

The purpose of the presented work is to establish the regularities of the operating processes of the adsorptive regenerator of heat and moisture in the ventilation system. To accomplish this, the following tasks are set:

- compile a mathematical model and develop a calculation algorithm of the processes of operation of the adsorptive regenerator of heat and moisture;

- to determine the basic design characteristics of adsorptive regenerators for a typical ventilation system in the housing and utilities sector;

- to establish the basic parameters of the processes of operation of the adsorptive regenerator.

\section{Experimental.}

The design of the adsorptive regenerator is presented in Fig. 1 [7]. The basic elementary units of suggested adsorptive heat regenerator are cylindrical case (pipe) (1), external (2) and inner (3) ventilators, checkerworks (4) fabricated from adsorptive heat storage material. Length of laboratory prototype of heat regenerator is $0.6 \mathrm{~m}$. As heat storage material composite sorbent 'silica gel - sodium sulphate' was used. It was synthesized by sol - gel method according to technique described in [5].

The device operational regimes are 'inflow' and 'outflow' which alternate one to another [7]. When exploited 'outflow' regime, air is intaken by ventilator 3 and released into outdoor environment. During 'inflow' regime the ventilator 3 is stopped, and ambient air being intaken by ventilator 2 and

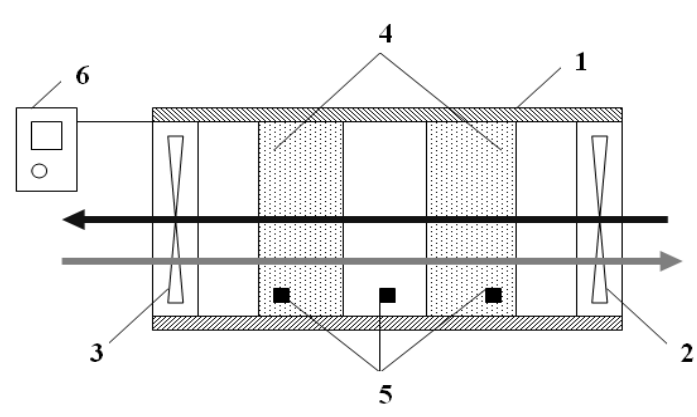

Fig.1. Heat regenerator construction

1 - pipe (case); 2 - external ventilator; 3 - inner ventilator; 4 - heat storage checkerworks; 5 - temperature detector; 6 - operating console [9]. got through checkerworks 4 into premise. When passed through the layer of heat storage material, air flow is heated, water excess being sorbed with checkerworks. So, temperature and humidity is kept constant, premise ventilation being realized. The outer end of investigated device is considered to be cold, the end placed in ventilated premise being warm.

\footnotetext{
Наукові праці, Том 82, випуск 1
} Scientific Works, Volume 82, Issue 1 


\section{Одеська національна академія харчових технологій \\ ТЕОРЕТИЧНІ ТА ЕКСПЕРИМЕНТАЛЬНІ ДОСЛІДЖЕННЯ ГІДРАВЛІЧНИХ, ТЕПЛОВИХ, \\ МАСООБМІННИХ ПРОЦЕСІВ}

According to the given stages, an algorithm for calculating the temperature efficiency coefficient of the adsorptive regenerator and the duration of its operation during the heating period has been developed (Fig. 2).

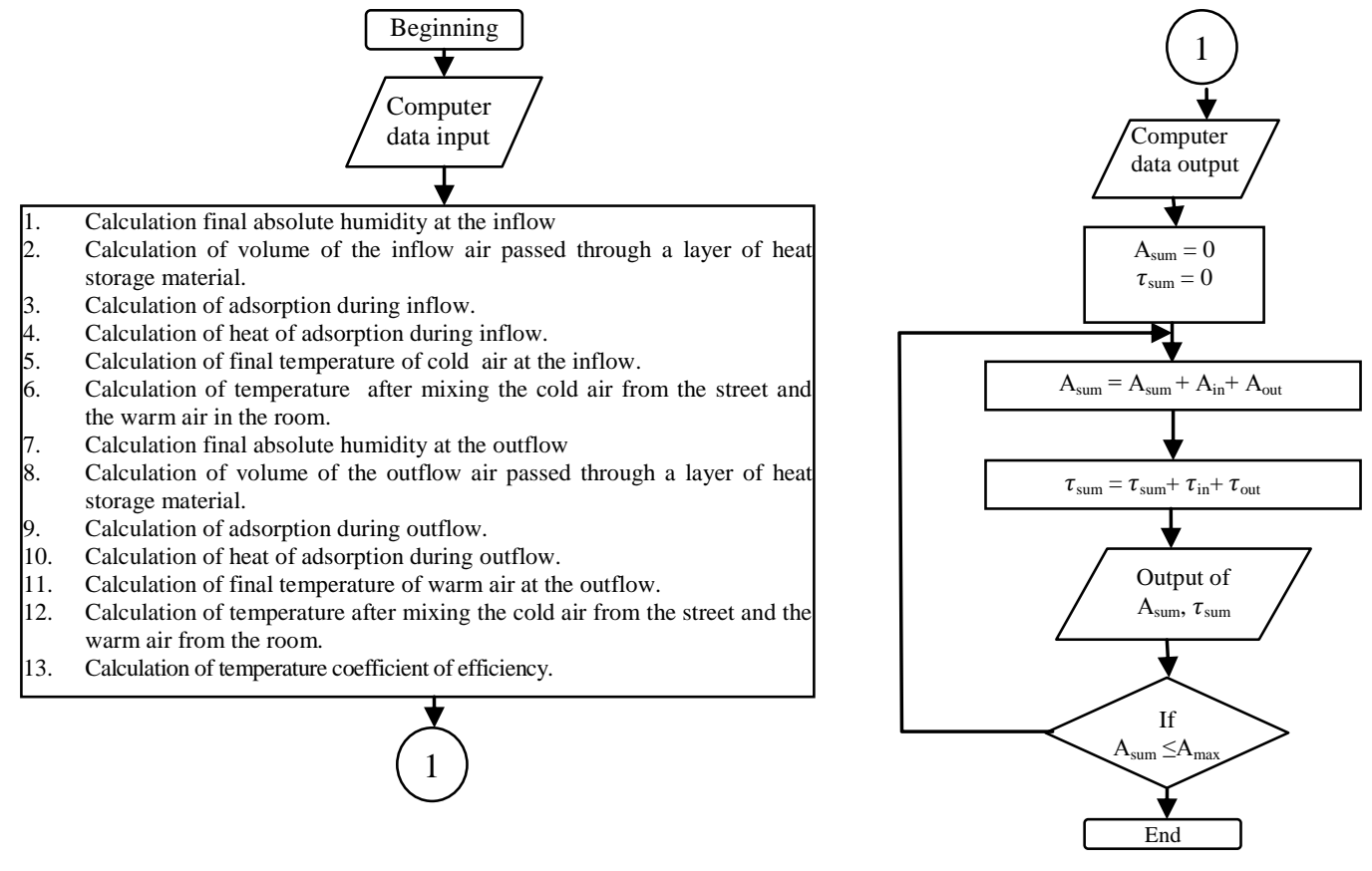

Fig. 2. Control-flow chart for calculation of efficiency factor of adsorptive regenerator.

The temperature coefficient of efficiency is determined by the formula:

$$
\eta_{\text {tem }}=\frac{t_{\text {inf }}-t_{\text {ext }}}{t_{\text {out }}-t_{\text {ext }}}
$$
air.

where $t_{\text {inf }}-$ temperature of inflowing air, ${ }^{\circ} \mathrm{C} ; \mathrm{t}_{\text {ext. }}-$ temperature of external air; $t_{\text {out }}-$ temperature of outgoing

Temperature of inflowing air is determined as a temperature after mixing the cold air from the street and the warm air in the room during inflow:

$$
\mathrm{t}_{\text {fin.r.aft.mix. }}=\frac{\mathrm{V}_{\mathrm{r}} \cdot \mathrm{t}_{\text {or }}+\mathrm{V}_{\text {inf }} \cdot \mathrm{t}_{\text {fin.r }}}{\mathrm{v}_{\mathrm{r}}+\mathrm{v}_{\text {inf }}}
$$

where $\mathrm{V}_{\mathrm{r}}$ - volume of premise, $\mathrm{m}^{3} ; \mathrm{t}_{0 . \mathrm{r}}-$ initial air temperature at the room outlet (warm end), ${ }^{\circ} \mathrm{C} ; \mathrm{t}_{\text {fin. } \mathrm{r}}-\mathrm{fi}$ nal temperature of the cold air-in, ${ }^{\circ} \mathrm{C}$.

Final temperature of cold air-in is calculated by equation of thermal balance:

$\mathrm{t}_{\text {fin.r }}=\left(\mathrm{C}^{\prime} \cdot \mathrm{t}_{0 \mathrm{str}} \cdot \mathrm{V}_{\mathrm{inf}}+4.19 \cdot \mathrm{t}_{0 \mathrm{str}} \cdot \mathrm{V}_{\mathrm{inf}} \cdot \mathrm{C}_{0 . \mathrm{str}}+\Delta \mathrm{H}_{\mathrm{ads.inf}} \cdot \mathrm{M}_{\mathrm{ads}}\right) /\left(\mathrm{C}^{\prime} \cdot \mathrm{V}_{\mathrm{inf}}+4.19 \cdot \mathrm{V}_{\text {inf }} \cdot \mathrm{C}_{\text {fin.r. }}\right)$

where $\mathrm{C}^{\prime}$ - volumetric specific heat of air, $\mathrm{kJ} / \mathrm{m}^{3} \cdot{ }^{\circ} \mathrm{C} ; \mathrm{t}_{0 \mathrm{str}}-$ temperature of outdoor air (near the cold end of regenerator), ${ }^{\circ} \mathrm{C} ; \mathrm{V}_{\text {inf }}$ - volume of the inflow air passed through a layer of heat storage material, $\mathrm{m}^{3} ; \mathrm{C}_{0 . \mathrm{str}}$. initial absolute humidity at the cold end of the regenerator, $\mathrm{kg} / \mathrm{m}^{3} ; \Delta \mathrm{H}_{\text {ads.inf }}$ - the heat of adsorption during inflow, $\mathrm{kJ} / \mathrm{kg} ; \mathrm{M}_{\mathrm{ads}}$ - mass of adsorbent, $\mathrm{kg} ; \mathrm{C}_{\text {fin.r }}$ - final absolute humidity at the inflow, $\mathrm{kg} / \mathrm{m}^{3}$.

The volume of air passed through the layer of heat storage material at the inflow or outflow, $\mathrm{V}_{\text {inf }}$ or $\mathrm{V}_{\text {outf }}, \mathrm{m}^{3}$ is calculated as:

$$
\mathrm{V}=\mathrm{F}_{s} \cdot \mathrm{W} \cdot \tau
$$

where $\mathrm{w}$ is speed of humid air, $\mathrm{m} / \mathrm{s} ; \tau$ is time of inflow or outflow, $\mathrm{s} ; \mathrm{F}_{\mathrm{s}}$ is area of the section, $\mathrm{m}^{2}$.

The temperature of the exhaust air is determined as the temperature after mixing the cold air from the street and the warm air from the room at the outflow:

$$
\mathrm{t}_{\text {fin.str.aft.mix. }}=\frac{\mathrm{v}_{\text {str }} \cdot \mathrm{t}_{0 . \text { str }}+\mathrm{v}_{\text {outf }} \cdot \mathrm{f}_{\text {fin.str }}}{\mathrm{v}_{\text {str }}+\mathrm{v}_{\text {out }}}
$$

where $\mathrm{V}_{\text {str }}$ is volume of air at the outside end of the regenerator, $\mathrm{m}^{3} ; \mathrm{t}_{0 . \mathrm{str}}$ is the initial temperature of the outside air when ejected from the room, ${ }^{\circ} \mathrm{C} ; \mathrm{t}_{\text {fin.str }}$ - final warm air temperature during outflow, ${ }^{\circ} \mathrm{C}$.

Final warm air temperature during outflow is calculated by thermal balance equation:

$$
\mathrm{t}_{\text {fin.str. }}=\frac{\mathrm{C}^{\prime} \cdot \mathrm{t}_{\text {or }} \cdot \mathrm{V}_{\text {outf }}+4.19 \cdot \mathrm{t}_{\mathrm{r}} \cdot \mathrm{V}_{\text {outf }} \cdot \mathrm{C}_{\mathrm{rr}}+\Delta \mathrm{H}_{\text {ads.outf }} \cdot \mathrm{M}_{\text {ads }}}{\mathrm{C}^{\prime} \cdot \mathrm{V}_{\text {outf }}+4.19 \cdot \mathrm{V}_{\text {outf }} \mathrm{C}_{\text {fin.str }}}
$$

where $C^{\prime}$ - volumetric specific heat of air, $\mathrm{kJ} / \mathrm{m}^{3} \cdot{ }^{\circ} \mathrm{C} ; \mathrm{t}_{0 \mathrm{r}}$ - temperature of indoor air (near the warm end of regenerator), ${ }^{\circ} \mathrm{C} ; \quad \mathrm{V}_{\text {outf }}$ - the volume of air passed through the layer of heat-accumulating material during outflow, $\mathrm{m}^{3} ; \mathrm{C}_{0 . \mathrm{r}}$. - initial absolute humidity at the warm end of the regenerator, $\mathrm{kg} / \mathrm{m}^{3} ; \Delta \mathrm{H}_{\text {ads.outf }}$ - heat of adsorption at the outflow, $\mathrm{kJ} / \mathrm{kg} ; \mathrm{M}_{\mathrm{ads}}$ - adsorbent mass, $\mathrm{kg} ; \mathrm{C}_{\text {fin.str }}$ - final absolute humidity at the outflow, $\mathrm{kg} / \mathrm{m}^{3}$. 
The heat of adsorption at the inflow or outflow is determined according to [9]:

$$
\Delta \mathrm{H}_{\mathrm{ads}}=\Delta \mathrm{h} \cdot \mathrm{A} \cdot \frac{1000}{\mathrm{M}_{\mathrm{w}}}
$$

where $\Delta \mathrm{h}$ is adsorption heat, $\mathrm{kJ} / \mathrm{mole}$; $\mathrm{A}$ is adsorption during inflow or outflow, $\mathrm{kg} / \mathrm{kg} ; \mathrm{M}_{\mathrm{w}}$ is molar mass of water, $\mathrm{g} / \mathrm{mole}$.

Adsorption at the inflow or outflow is calculated similarly [9]:

$$
A=\frac{C_{0}-C_{\text {fin }}}{M_{\text {ads }}} \cdot V
$$

where $\mathrm{V}$ is air volume, $\mathrm{m}^{3} ; \mathrm{C}_{0}$ is initial absolute humidity at inflow or outflow, $\mathrm{kg} / \mathrm{m}^{3} ; \mathrm{C}_{\text {fin }}$. is final absolute humidity at inflow or outflow, $\mathrm{kg} / \mathrm{m}^{3} ; \mathrm{M}_{\mathrm{ads}}-$ adsorbent mass, $\mathrm{kg}$.

Final absolute humidity at the outlet of the regenerator during inflow or outflow is determined according to [9]:

$$
\mathrm{C}_{\text {fin }}=\frac{\mathrm{C}_{0}}{\mathrm{e}^{\frac{\left[\beta \cdot \frac{\left(-\tau \cdot \mathrm{w} \cdot \mathrm{C}_{0}\right)}{\mathrm{Amax}_{\max }}+\mathrm{H}\right]}{\mathrm{w}}+1}}
$$

where $\mathrm{A}_{\max }$ is limiting adsorption, $\mathrm{kg} / \mathrm{kg} ; \beta$ is mass transfer coefficient, $\mathrm{s}^{-1} ; \mathrm{w}$ is speed of humid air, $\mathrm{m} / \mathrm{s} ; \mathrm{H}$

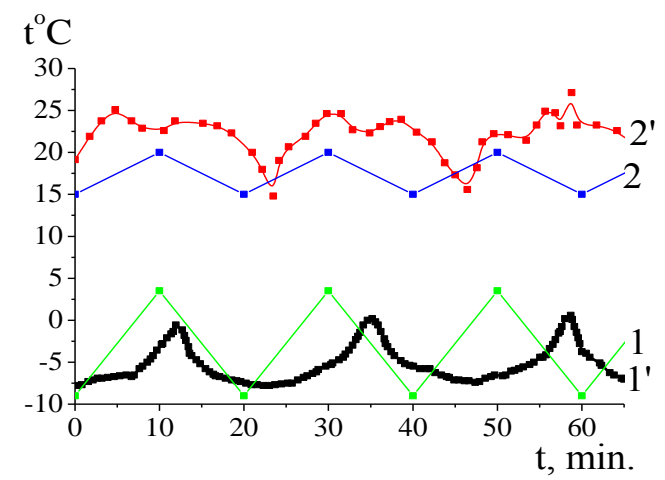

Fig. 3. Comparison of experimental and computed data: 1, 1' - temperatures at the cold end of the regenerator; 2, 2' - temperatures at the warm end of the regenerator; 1,2 - calculated data: 1'. 2' - experimental data.

is thickness of the heat storage material layer, $\mathrm{m} ; \tau$ is is time of inflow or outflow, $\mathrm{s}$.

The coefficient of mass transfer was calculated similarly to [9]: $\beta=\left(\frac{1}{\beta_{\mathrm{y}}}+\frac{1}{\beta_{\mathrm{lc}}}+\frac{1}{\beta_{\mathrm{p}}}\right)^{-1}$

where $\beta_{\mathrm{y}}, \beta_{l c}, \beta_{p}$-coefficients of mass transfer in the gas phase, in the longitudinal cross section and pores, $\mathrm{s}^{-1}$.

Furthermore, summarized adsorption and maximal adsorption time are calculated according to control-flow chart (Fig. 2).

Results and discussion. Experimental data presented in [7] have been used to validate the proposed calculation algorithm. The results of the calculations showed the periodic dependence of the temperatures on the cold and warm ends of the adsorptive regenerator (Fig. 3, curves 1 and 2), which qualitatively corresponds to the

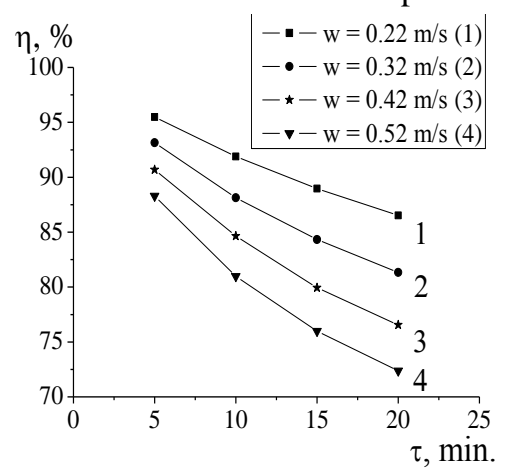

Fig. 4. Temperature efficiency coefficient (a) and maximal adsorption time (b) vs. air-flow rate. experimental data (Fig. 3, curves 1 'and 2'). The deviation of the calculated temperatures from the experimental does not exceed 2 $-3^{\circ} \mathrm{C}$ at the cold end of the regenerator, and $1-5^{\circ} \mathrm{C}$ on the warm.

The temperature efficiency coefficient of the regenerator according to the experimental data is approximately $95 \%$, and according to the calculated approximately $91 \%$. So, this mathematical model can be used for qualitative evaluation of the performance characteristics of adsorptive regenerators in ventilation systems. An adsorptive regenerator is proposed to apply for the heating of the inflow air in the conditions of a typical three-room apartment with electric cookers, a total area of $103 \mathrm{~m}^{2}$, a height of 2.5 meters. According to the results of the calculation by the Sanitary Regulations 2.04.05-91, the thermal load for heating the supply air is about $327.9 \mathrm{MJ}$ per a day.

As an adsorptive material, the composite containing $20 \%$ silica gel and $80 \%$ sodium sulfate is suggested to use. The weight of the sorbent corresponding to the thermal load is estimated at $94 \mathrm{~kg}$ and the volume is $0.130 \mathrm{~m}^{3}$. Thus, it will be an optimal option to install in the scheme of 3bedroom apartments four adsorptive regenerators. Then, the mass of the sorbent on the regenerator is $24 \mathrm{~kg}$. The results of the calculations are presented in Fig. 4 and 5. Under typical living conditions, the temperatures on the warm and cold ends of the regenerator are observed to be periodically changed. Moreover, with a decrease in the time of switching (change of direction) flows, there is a significant decrease in the amplitude of the dependencies of temperature vs. switching time, both on the warm and the cold ends of the device. This resulted in the increase of the efficiency coefficient (Fig. 4). The time to reach maximal adsorption from the time of switching flows occurs to be almost independent. More significantly, it is affected by the speed of the flow of humid air, which is resulted from the amount of air supplied. When the speed of the flow of humid air decreased from 0.52 to 0.22 $\mathrm{m} / \mathrm{s}$, maximal adsorption time is observed to increase from 25 to 135 hours. 


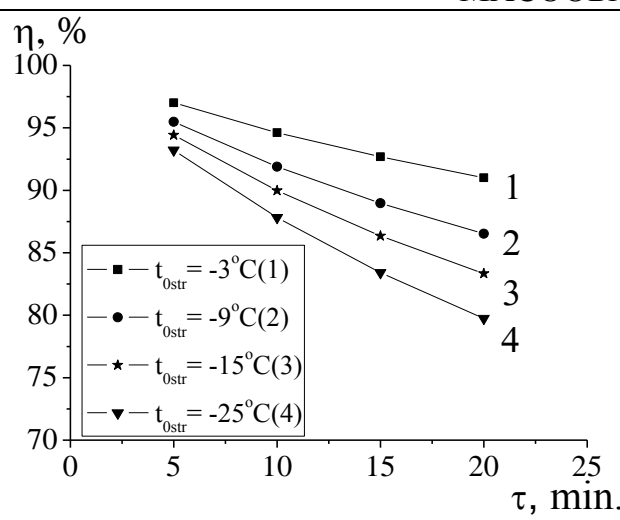

a

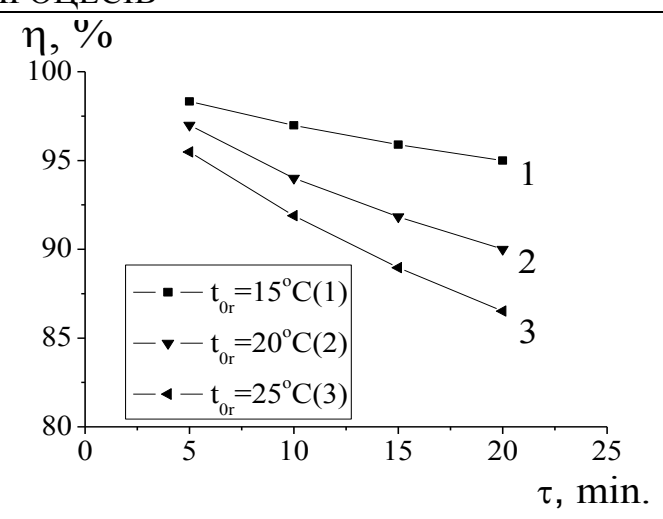

b

Fig. 5. Temperature efficiency coefficient vs. flows switching time and temperature of external air (a) and temperatures of inside air (b).

The maximum values of the efficiency coefficients are observed at the flow rates of the moist air of 0.22 $0.32 \mathrm{~m} / \mathrm{s}$ and the time of switching the flows of about $5 \neg 10 \mathrm{~min}$. Also, the performance of the heat accumulation device is influenced by meteorological conditions, that is, the temperature of the outside air (Fig. 5a), with the increase of which the temperature efficiency coefficient of the regenerator increases. The temperature of the external air appeared to be almost unaffected by the time to reach maximal adsorption. Decrease in the space air temperatures results in the increase in the temperature efficiency coefficient (Fig. 5b).

\section{Conclusions}

The research of processes of operation of the ventilation system on the basis of adsorptive regenerator of heat and moisture was conducted. The method of determination of the main performance characteristics of the adsorptive regenerator in the conditions of the ventilation system in the residential premises is developed.

1. The dependence of the value of the temperature coefficient of useful efficiency on the velocity of the steam-air flow and the time of switching flows is shown. The maximum values of the efficiency coefficients are observed at the velocity of the flow of moist air of $0.22-0.32 \mathrm{~m} / \mathrm{s}$ and the time of switching the flows about $5 \neg$ 10 minutes.

2. The dependence of the temperature efficiency coefficient on the temperature of the external and internal air is established. The growth of the efficiency coefficient is shown when the temperature of the outside air increases from $-25^{\circ}$ to $-3^{\circ} \mathrm{C}$.

\section{References}

1. Östin R. Evaluation of a Single Family Low Energy Building in Cold Climate // Energy Procedia. - 2017. - Vol. 132. - P. 9 - 14.

2. Данилевский Л. Н. Системы принудительной вентиляции с рекуперацией тепловой энергии удаляемого воздуха для жилых зданий[Текст]/ Л. Н. Данилевский. - Минск, 2014. - 128 с.

3. Manyumbua E., Martin V., Fransson T. Simple mathematical modeling and simulation to estimate solar-regeneration of a silica gel bed in a naturally ventilated vertical channel for Harare, Zimbabwe // Energy Procedia. 2014. - Vol. 57 - P. 1733 - 1742

4. Kubota M., Hanaoka N., Matsuda H., Kodama A. Dehumidification behavior of cross-flow heat exchanger type adsorber coated with aluminophosphate zeolite for desiccant humidity control system// Appl. Thermal Eng. - 2017. - Vol. 122. — P. 618-625

5. Structure and Adsorption Properties of the Composites 'Silica Gel - Sodium Sulphate', obtained by Sol - Gel Method / Sukhyy K.M., Belyanovskaya E.A., Kozlov Ya.N., Kolomiyets E.V., Sukhyy M.P. // Applied Thermal Engineering. - 2014. - Vol. 64. - P. 408 412.

6. Аристов Ю.И., Мезенцев И.В., Мухин В.А. Новый подход к регенерации теплоты и влаги в системе вентиляции помещения. II. Прототип реального устройства // Инженерно-физический журнал. - 2006. - Т. 79, № 3. - С. 1 - 7

7. Kolomiyets, O.V. Operating characteristics of adsorptive regenerator of low-potential heat and moisture based on composite sorbents 'silica gel - sodium sulphate and silica gel - sodium acetate' synthesized by sol - gel method [Text] / O. V. Kolomiyets, K. M. Sukhyy, E. A. Belyanovskaya, V. I. Tomilo, O. M. Prokopenko // Наукові праці ОНАПТ. - 2016. - Т. 80, вип. 1. - C. 108 - 113.

8. Scapino L., Zondag H. A., Van Bael J., Diriken J., Rindt C. C. M. Sorption heat storage for long-term low-temperature applications: A review on the advancements at material and prototype scale // Applied Energy. -2017. - Vol. 190. - P. 920-948.

9. Belyanovskaya E. A., Sukhyy K.M., Kolomiyets O.V., Sukhyy M.P. Operating processes parameters of open-type heat storage devices in heat supply systems // Наукові праці ОНАХТ. - 2017. - Т. 81, вип. 1. - С. 4 - 9.

\section{References}

1. Östin R. (2017). Evaluation of a Single Family Low Energy Building in Cold Climate. Energy Procedia, 132,9 - 14

2. Danilevskiy, L.. N. (2014). Systemy prinuditelnoy vetilyatsii s rekuperatsiyey teplovoy energiyi udalyaemogo vozdukha dlya jilykh zdaniy. Minsk, 128

3. Manyumbua, E., Martin, V., Fransson, T. (2014). Simple mathematical modeling and simulation to estimate solar-regeneration of a silica gel bed in a naturally ventilated vertical channel for Harare, Zimbabwe. Energy Procedia, 57, 1733 - 1742

4. Kubota, M., Hanaoka, N., Matsuda, H., Kodama, A. (2017). Dehumidification behavior of cross-flow heat exchanger type adsorber coated with aluminophosphate zeolite for desiccant humidity control system. Appl. Thermal Eng., 122, 618-625

5. Sukhyy, K.M., Belyanovskaya E.A., Kozlov Ya.N., Kolomiyets E.V., Sukhyy M.P. (2014). Structure and Adsorption Properties of the Composites 'Silica Gel - Sodium Sulphate', obtained by Sol - Gel Method. Applied Thermal Eng., 64, 408 - 412.

6. Aristov, Yu. I., Mezentsev, I. V., Mukhin, V. A. Novyi podkhod k regeneratsii ntgkjne s vlagy v systeme ventilyatsii pometsheniya. II. Prototyp realnogo ystroystva. Inzenerno-phyzicheskiy jurnal., 79(3), 1 - 7 
7. Kolomiyets, O. V., Sukhyy, K. M., Belyanovskaya, E. A., Tomilo, V. I., Prokopenko, O. M. (2016). Operating characteristics of adsorptive regenerator of low-potential heat and moisture based on composite sorbents 'silica gel - sodium sulphate and silica gel - sodium acetate' synthesized by sol - gel method. Scientific works ONAFT, 80(1), $108-113$.

8. Scapino, L., Zondag, H. A., Van Bael, J., Diriken, J., Rindt, C. C. M. (2017). Sorption heat storage for long-term low-temperature applications: A review on the advancements at material and prototype scale. Applied Energy, 190, 920-948.

9. Belyanovskaya, E. A., Sukhyy, K. M., Kolomiyets O. V., Sukhyy M. P. Operating processes parameters of open-type heat storage devices in heat supply systems. Scientific works ONAFT, 81(1), $4-9$.

This work was supported by Government Fund for Fundamental Research, Ukraine (grant number 0118U003343).

Отримано в редакцію 05.05.2018

Прийнято до друку 30.06.2018
Received 05.05.2018

Approved 30.06.2018

\title{
ВАКУУМНІ МІКРОХВИЛЬОВІ ТЕХНОГІї ПРИ ВИРОБНИЦТВІ ФІТОПРЕПАРАТІВ 3 ПЛОДІВ ШИПШИНИ
}

\author{
Левтринська Ю.О., к.т.н., асиситент, Альхурі Юсеф, аспірант, \\ Голінська Я.А., асистент, Терзісв С.Г., д.т.н. \\ Одеська національна академія харчових технологій, м. Одеса
}

\begin{abstract}
Анотація. У даній статті представлено результати досліджень процесів екстрагування у мікрохвильовому полі в умовах зниженого тиску. Об'єктом досліджень обрано плоди шипшини - багаті на термолабільний вітамін С. При екстрагуванні у створеному зразку екстрактора температури не перевищують $50{ }^{\circ} \mathrm{C}$. За таких температур зберігається більше вітаміну С, краще зберігається колір та смак. Проведені лабораторні дослідження підтверджують підвищений вміст вітаміну С у екстракті. У порівнянні з технологіями, які зараз застосовуються на фармацевтичних підприємствах при виробництві екстрактів шипшини створені екстрактор та випарна установка мають ряд переваг: проста конструкція, безпечність, знижені робочі температури, енергетична ефективність. Підвищення виходу екстрактивних речовин можна пояснити особливим протіканням процесу за умов впливу мікрохвильового поля та виникненню явища бародифузї, щуо значно інтенсифікує перехід компонентів, щзо містяться у капілярах до екстракту.
\end{abstract}

Ключові слова: екстрагування, випаровування, фітопрепарати, мікрохвильове поле, кріоконцентрат.

\section{VACUUM MICROWAVE TECHNOLOGIES IN THE PRODUCTION OF PHYTOPREPARATIONS FROM ROSE HIPS}

\author{
Levtrynskaya J.O., PhD in Tech.Sci., assistant, Alhuri Usef, postgraduate student, \\ Golynskaya Ya.A., assistant, Terziev S.G., Dr. in Tech.Sci. \\ Odessa national academy of food technologies, Odessa, Ukraine
}

\begin{abstract}
In this paper are presents the results of studies of extraction processes in a microwave field under conditions of reduced pressure. The object of research are the rose hips - rich in thermolabile vitamin $C$. According to previous studies, under the action of the microwave field possible reach a significant intensification of extraction processes. This is due to barodiffusion - a phenomenon that occurs in the capillaries of plant material. These principles are the base for innovative facilities designed by our scientific group: a microwave vacuum extractor and a microwave vacuum evaporator. During the sample treatment in an extractor, the temperature does not exceed $50{ }^{\circ} \mathrm{C}$. At these conditions saved more of vitamin $C$, color and taste are better preserved. The laboratory researches confirm that the high content of vitamin $C$ is present in the extract. Compared to the technologies that are applied be pharmaceutical companies in the production of rose hips extracts and evaporators, they have several advantages: simple design, safety, reduced working temperatures, high energy efficiency, shortening of processes. With microwave extraction it is possible to obtain the extracts that contain non-typical components for aqueous extracts precisely due to barodifusion. So, with the use of one solvent, can be obtained a polyextract on the same installation. These technologies are actual in the first place for the pharmaceutical industry and the market of health food products. The comparison of vacuum microwave and cryoconcentration technologies are performed. It is wellknown that the best way to concentrate products with high vitamin $C$ content is cryoconcentration. Obtained in that research results indicate that the quality of the extract produced in the vacuum microwave evaporator is similarly to cryoconcentrate.
\end{abstract}

Key words: extraction, evaporation, phytopreparations, microwave field, cryoconcentrate. 